\title{
CHP Yardım Sandığının Kurulması ve Lağvedilmesi
}

\author{
Ahmet İLYAS \\ Batman Üniversitesi \\ ahmetilyas@hotmail.com \\ ORCID ID:0000-0001-9578-9160
}

Araştırma Makalesi

Geliş Tarihi: 26.02.2020

Revize Tarihi: 15.02.2021

DOI: $10.31592 /$ aeusbed.694617

Kabul Tarihi: 25.02.2021

\section{Atıf Bilgisi}

İlyas, A. (2021). CHP yardım sandığının kurulması ve lağvedilmesi. Ahi Evran Üniversitesi Sosyal Bilimler Enstitüsü Dergisi, 7(1), 85-98.

\section{$\ddot{\mathbf{O Z}}$}

İkinci Dünya Savaşı'na Türkiye fiili olarak girmemesine rağmen, savaşa girmiş bir ülke kadar ciddi sıkıntı yaşadı. Çünkü üretici konumunda olan çalışan nüfus, bir anda silah altına alınmıştır. Silah altına alınan çalışan nüfus artık tüketici hale geldi. Savaşın getirmiş olduğu yıkım sadece fiziksel değildi. Zihinsel bir yorgunluğu da beraberinde getirmişti. Bilhassa savaş sırasında ithalatın çok pahalı olması hasebiyle ülke ekonomisi durma noktasındaydı. Ancak yine de Türkiye bu dönemde kendi kendine yeten bir ülke haline gelmeye çalıştı. Öyle ki bu durum yaşam için sadece gerekli olan gıda ve tüketim mallarının tükenmesine sebep oldu. Devlet, bu hızlı tükeniş karşısında çıkarmış olduğu kanunlarla halka yardım etmeye çalıştıysa da başarılı olamadı. Bu süre zarfında istifçilik karaborsacılık da yaygınlaşmaya başladı. Bu çalışmada dünya savaşının getirmiş olduğu sosyal ve ekonomik sorunların azaltılması amacıyla Cumhuriyet Halk Partisi (CHP) Genel Sekreterliğine bağlı yardım sandığını konu almaktadır. Yardım sandığı kendisine üye olan kişilerin ekonomik sorunlarına yardımcı olmaya çalışırken, öte yandan parti içi duygusallık düzeyinin de artırılmasına yardımcı olmaya çalışmıştır. Çalışmada yardım sandığına başvuran kişilerin hangi sebeple başvuru yaptığı da özellikle değinilmiştir. Ayrıca yaklaşık on yıl boyunca çalışmalarını sürdüren yardım sandığının her yıl düzenli olarak yaptığı toplantı ve değerlendirmeler de bu çalışmanın içeriğinde yer almaktadır. Çalışmanın son kısmında yaşanan iktidar değişikliği birlikte yardım sandığının kapatılması ve üyelerin birikimlerini yardım sandığından alması da bulunmaktadır.

Anahtar Kelimeler: CHP, yardım sandığı, genel sekreterlik, ikinci dünya savaşı.

\section{Rpp's Help Fund Estaplısment And Closing}

\begin{abstract}
Turkey entered World War II, although as the actual, serious difficulties have lived up to a country at war. Because the working population, who is a producer, is immediately under armament. The recruited working population has now become a consumer. The destruction brought by the war was not just physical. It brought with it a mental fatigue. Especially during the war, imports were stopped due to the fact that it was too expensive. Turkey tried to just come into a country self-sufficient in this period. So much so that this caused the depletion of food and consumer goods necessary for life. Although the state tried to help the people with the laws it had made against this rapid exhaustion, it was not successful. During this time, hoarding began to become widespread. This study focuses on the RPP General Secretariat aid fund to reduce the social and economic problems brought by the world war. While trying to help the economic problems of the members of the aid fund, he also tried to help increase the level of emotionality within the party. In the study, the reason for which the applicants applied to the aid fund applied was also specifically mentioned. In addition, the meetings and evaluations held regularly every year by the aid fund, which has been working for about ten years, are also included in the content of this study. In the last part of the study, the change in power was closed together with the aid chest and the members got their savings from the aid fund.
\end{abstract}

Keywords: RPP, aid fund, general secretariat, second world war.

\section{Giriş}

Mondros Ateşkes Antlaşması'nın imzalanmasıyla birlikte Anadolu, İtilaf Devletleri tarafından işgal edilmeye başlanmıştır. İşgaller karşısında halk kendini korumak amacıyla Kuvay-ı Milliye denen milis güçler oluşturmuş̧lardır. Diğer taraftan birçok vilayette de Müdafaa-i Hukuk Cemiyetleri teşekkül ettirilmiştir. Bu cemiyetler, halkın işgallere karşı bilinçlenmesinde önemli bir vazifeyi üstlendiler. Samsun'da Müslüman ile Rum ahali arasındaki silahlı çatışma üzerine İngilizler, bölgede sükunetin sağlanması ve silahların toplanmasını Osmanlı Devleti'nden istediler. Devleti Aliyye de buraya sükûnetin sağlanması ve silahların toplanması amacıyla Mustafa Kemal Paşa'yı gönderdi. Mustafa Kemal, Samsun'a ulaştıktan sonra mücadele fikrini halka aşılamak amacıyla Havza 
Genelgesi'ni yayınlamış akabinde Amasya Genelgesi ilan edilmiş, Erzurum ile Sivas Kongrelerini gerçekleştirmiştir. Bu kongreler neticesinde oluşturulan Heyet-i Temsilliye bir hükümet gibi hareket ederek temsil ruhunun devam etmesine yönelik önemli bir vazifeyi üstlenmiştir. Heyet-i Temsiliye Ankara'ya geldikten sonra İstanbul Hükümeti ile yapılan görüşmeler 1şı̆̆ı̆nda İstanbul'da Meclis'in açılması çalışmalarını üstlendi. Yapılan seçimler sonrasında İstanbul'da Meclis-i Mebusan İstanbul'da toplandı. Osmanlı Mebusan Meclisi İstanbul'da açıldıktan sonra alınan Misak-i Milli kararları neticesinde 16 Mart 1920 tarihinde Osmanlı başkenti İstanbul, İtilaf Devlerince işgal edilince Mustafa Kemal Paşa, Ankara'da kurucu ve milli bir meclis açmak için ordu komutanları ile valilere telgraf gönderdi. Yapılan seçimler neticesinde 23 Nisan 1920 yılında Ankara'da Büyük Millet Meclisi açıldı.

İstiklal Harbi'nin yürütülmesinde önemli bir görevi üstlenen birinci meclis, devletin kurtarılması ve kurulmasında mücadele verdikleri için aynı zamanda kurucu meclis ünvanını da almıştı (Hafızoğulları, 2000, s. 291). Kurucu meclis içerisinde vazifesini sürdürmeye çalışan milletvekilleri dönemin şartları içerisinde ciddi sıkıntılar yaşadıkları anlaşılmaktaydı. Öyle ki ilk Meclis'te milletvekillerinin oturacağı sıralar dahi bulunmuyordu (Şapolyo, 1969, ss. 6-7). Özetle Millî Mücadele zor şartlar altında sürdürülmeye çalışıyordu.

Millî Mücadele'nin yürütülmesinde sıkıntı yaşayan sadece milletvekili, ordu mensupları ya da halk değildi. Devlet işlerini yürütmeye çalışan devlet personeli de o dönem için ciddi sıkıntılar yaşıyordu. Savaş ortamı içinde devlet personeli bir yandan görevini yapmaya çalışıyorken diğer taraftan mali konularda da sorunların ortasındaydılar. Öyle ki Millî Mücadele'nin ilk yıllarında devlet memurluğu, boğaz tokluğuna yapılan bir vazife olarak telakki ediliyordu (Avcığlu, 1996, s. 417). Özellikle konut yetersizliği, maaşların düşüklüğü, çalışan kesim tarafından sık s1k dile getirilen konular arasında yer almaktaydı (Kansu, 1986, s. 570). Konut bulamayanların çoğu Muallim Mektebi yani Maarif Vekâleti'nde kalırlardı. Diğer taraftan Ankara'da yaşanan hayat pahalılığı kira yardımının memurlara yönelik yapılmaması önemli sorunlar arasında yer alıyordu (Berktaş, 2014, s. 169). Aylarca maaş alamayan memurlar bile bulunuyordu (Avcioğlu, 1996, s. 416). Hatta Meclis'in ilk günlerinde sekiz ayda bir maaş alan memurlar bile vardı (Gündoğdu, 2004, s. 27).

Memurların maaşları genellikle her ay ödenen bir maaş değildi. Savaştan çıkmış bir devlet olarak Türkiye 1926 yılına kadar memurlara düzensiz bir ödeme yapardı. 31 Mart 1926 yılında çıkarılan 788 nolu Memurin Kanuni ile memurların yasal dayanağı oluşturuldu (Türkiye Büyük Millet Meclisi Zabıt Ceridileri [TBMM ZC], C. XXI, D. II, 31.03.1926, s. 509). Buna göre memurun derecesine göre en az 10 en çok 150 lira maaş alması kabul edilmiştir (Ataay, 1974, s. 434). Memur maaşlarında verginin alınmaması 1931 yılına kadar kısmen memurların rahat bir yaşam sürmelerini sağlamıştır. Ancak yaşanan ekonomik sıkıntılarla birlikte maaşlardan belli oranda vergi alınması üzerine 1452 numaralı kanunla maaşlar yeni düzenlenmiş buna göre en yüksek memur maaşı genel müdür 90 lira, müdür 45 lira, en düşük memur maaşı ise evrak ve dosya memuru 16 lira, levazım memuru 12 lira olarak hesaplanmıştır. Savaşın ortaya çıkışıyla birlikte devlet, memurların rahat nefes alması için birtakım düzenlemeler yapmıştır. Buna göre İsmail Durak savaş süresi boyunca memurlara sağlanan avantajları şöyle sıralamaktadır.

“1942 yılında 4178 sayılı kanunla, maaşlara \%15-25 arasında zam yapılmıştır. Bu zam olağanüstü durum süresince düşünülmüştür. Bu değişiklikle, 3 çocuktan sonraki çocuklar için, ayrıca 2,5 lira çocuk zammı verilmesi kabul edilmiştir. Ankara'da oturan memurlara, mesken tazminatı verilmesi, 1500 metreden yüksek yerde oturan memurlara, Ekim ayından Mart ayına kadar her ay için 15-30 lira yakacak zammı verilmesi kabul edilmiştir. Yapılan bu zamlardan, vergi ve emeklilik kesilmeyeceği kanunlaşmıştır” (Ataay, 1974, s. 436).

\section{CHP Yardım Sandığının Kurulması}

İkinci Dünya Savaşı'nın getirmiş olduğu ağır ekonomik baskı ve çalışan nüfusun bir anda üretici hale gelmesi üretim ekonomisine zarar vermeye başlamıştı. Savaş koşulları içerisinde ülke ekonomi gündemini en çok meşgul eden husus ise karaborsa, pahalılık ve tefecilikti. Devlet bu kişilerle Milli Korunma Kanunu vasıtasıyla mücadele etmeye çalışmıştır (Tekeli ve İlkin, 2014, s. 86). 
Öte yandan halkın enflasyon karşısında ezilmesini önleme adına Fiyat Murakabe Komisyonları kurulmuştur. Ancak tüm bu yapılanlara rağmen devlet tefeci ve karaborsacılarla mücadele etme konusunda yeterince başarılı olduğu söylenemez (Toker, 1998, s. 24). Yakup Kadri, savaş sırasında Türk toplumunun yaşadığı sıkıntıları anlatırken kullandığı şu ifadeler olayın vahameti açısından önem taşımaktadır:

\begin{abstract}
"Memleket öylesine bir ekonomik buhran içine düşmüştü ki, bir lokma has ekmekten, bir avuç, şekerden tutun da bir kilo çiviye kadar bütün «zaruri havâyic» altın pahasına elde edilebilir lüks maddeler sırasına girmiş ve geçim sıkıntısı harp halinde bulunan memleketlerde bile görülmeyen bir vahamet arzetmeye başlamıştı" (Karaosmanoğlu, 1984, s. 184).
\end{abstract}

Yaşanan bu çöküntü Meclis kürsüsünde de dile getirilmeye çalış1lıyordu. Ticaret Vekili Mümtaz Ökmen, "Memlekette ihtikar yok değildir, hükûmetin aldığı tedbirlere rağmen bizim aziz yurdumuzda da ihtikar (vurgunculuk) yapan ve burada 1srar etmek isteyen bir zümre vardır" (Boratav, 1990, s. 253) diyerek istifçilere subniminal mesaj vermekteydi.

Savaş koşulları içerisinde iaşe ve kentlerdeki pahalılıkta önemli bir sorundu (Metinsoy, 2016, s. 66). Şehirde yaşayanlar, en basit olarak gıda sorununa bile çare bulamaz haldeydi. Dönemi hikâye eden Faik Ahmet Barutçu savaşın getirdiği yokluğu şu ifadelerle tasvir etmiş̧ir: "Açlık 1stırabı giderek genişlemektedir. Pirinç, yağ, et gibi ana maddeleri bulmakta güçlük çeken kentlerimiz eksik değildir. İstanbul gibi en nemli bir merkez yiyecek sıkıntısına düşmüştür” (Barutçu, 1977, s. 250). Tüm bunların yanında savaşın getirmiş olduğu şartlardan yararlanmaya çalışan sadece tefeciler ve karaborsacılar değildi. Bu durumdan firsat çıkaran ve ticari ilişki ağını genişletmeye çalışan bazı üst düzey memur ve milletvekillerinin olduğu birçok teftiş raporunda yer almaktaydı (Timur, 1994, ss. 21 22). Memur maaşlarının az olması, yaşanan ekonomik kriz, memurların bu denli işlere girmesine sebebiyet veriyordu (Ergin, 1943, s. 115). Diğer taraftan çalışanlar ve halkın yaşadığı ekonomik sorunlar, tahıl, hububat üretiminin düşmesi, ekmeğin karneye bağlanması ve yeni getirilen vergiler halkın başlıca sıkıntısı iken, memurlar da bu sıkıntıdan etkilenen gruplar arasındaydı (Pektaş, 2003, s. 263). Özellikle reel ücretlerde yaşanan düşüş, maaşların enflasyon karşısında erimesi en çok konuşulan meseleler arasındaydı. Hatta mevcut durumu Milli Şef'e iyi bir şekilde gösterildiğine dair dönemin yazarlarının anılarında yer almaktaydı. Örneğin Yakup Kadri, bir memurun İsmet İnönü’nün bizzat yanına gelerek:

\footnotetext{
"Paşam, ben şimdi bir devlet memuruyum, siz ise devlet başkanısınız. Fakat, müsaade ediniz konuşayım. İstanbul'dan geliyorum; orada görüp işittiklerimden çok üzgünüm. Hükûmete ve hattâ size, sizin sahsınıza karşı adeta husumet derecesine varmış, bir muhalefet cereyanı alıp yürümektedir. Sakın, memleketi harp felaketinden kurtardığınız için halkın size minnettar olduğu hayaline kapılarak, bu cereyanı mühimsememezlik etmeyin. Bunun sebeplerini bizzat araştırmaya bakın. Bizzat diyorum etrafınızdakilerin memleket realitelerini sizden gizlediklerini ve size her tarafı güllük gülistanlık gösterdiklerini biliyorum. Zira, size gelmezden önce bazı eski meclis arkadaşlarımla bu bahis üzerinde konuşmak isteyince sözümü ağzıma tıkadılar: Aman, bize söylediklerinizi gidip Paşa’ya da tekrar etmeye kalkışma, üzülür” dediğine tanık olduğunu belirtmektedir (Karaosmanoğlu, 1984, s. 185).
}

Devlet, memurlarını enflasyon karşısında ezdirmemek adına birçok yardım programını yürürlüğe sokmuştur. Başta halkevlerinin yardım kolu olmak üzere memurlara elbise ve gıda yardımı yapılmaya çalışılmıştır. Hatta Müstakil Grup tarafından hazırlanan raporlar neticesinde maaşı düşük olan memurlarına ücretsiz ekmek verilmesi, il ve ilçelerde memur kantinlerinin açılması, gıda yardımlarının yapılması kararlaştırılmıştır (Tuğluoğlu, 2001, s. 360). Öte yandan 13 Kasım 1942 tarihinde Meclise sevk edilen yasayla memur ve müstahdemlere birer çift ayakkabı ve elbise verilmesi kabul edilmiştir (TBMM, C. XXIX, D. VI, 16.12.1942, ss. 24-25). Tüm bunların yanında dört ya da daha fazla çocuğu olanlara devlet tarafindan memurlara nakdi yardım yapılmıştır (Tuğluoğlu, 2001, s. 368). Memurlara, ayni yardım yapılarak kuponlar verilmiş ve ucuz gıdaya ulaşmasının önü açılmıştır. Öte yandan seyahat edecek memurların tren biletlerinde indirim yapılması da sağlanmıştır. Devletin memurlara yönelik sağladığı bu kolaylıklar halkın memurlara garez beslemesine, memurların devlet 
tarafından verilenleri fahiş fiyatla satmaya başlaması, toplum tarafindan kötü bir ün kazanmalarına sebebiyet vermiştir.

Devlet, memurların yaşanan sıkıntılardan kurtarmak için birçok yolu denerken, diğer taraftan CHP Genel Sekreterliği de kendisine bağlı memurların yaşadığı sıkıntıların farkındaydı. Bu sıkıntıların giderilmesi için birçok kez şikâyet mektupları da gelmiş oluyordu. Özellikle Genel Sekreterliğe bağlı onuncu büro memurları, genel sekreterliğe bağlı memurların ihtiyaçların giderilmesi amacıyla genel sekterliğe bağlı bir yardım sandığının kurulması fikri uzun süredir dillendiriliyordu (Başbakanlık Cumhuriyet Arşivi [BCA], 490.01/84.311.1/3). Genel Sekreterlik de parti bilişsel düzeyini artırmak, partililer arasında solidarist dayanışma anlayışı oturmak amacıyla ve CHP'ye üye kişi ve kamu görevlilerinin ekonomik çıkarlarını korumak ve ihtiyacı olan kişilere ekonomik likitide oluşturmak amacıyla 17 Ocak 1942 tarihinde CHP Genel Sekreterliği bünyesinde CHP Memurları Yardım Sandığ1 kurulması kararını almıştır (BCA, 490.01/93.365.4). Genel Sekreterliğe bağlı kendi içinde işleyişs biçimi olan bu kuruluş müdde-i 15 yıldır denilerek 1957 yılına kadar varlığını devam ettirmeyi hedeflemiştir (BCA, 490.01/84.311.1/4). Yardım sandığının kuruluş amacı şöyle ifade edilmiştir: "Cumhuriyet Halk Partisi Genel Sekreterlik Memurları ve müstahdemleri tarafindan ve bunlara mahsus olmak üzere bir biriktirme ikraz sandığı kurulmuştur. Buna göre 1-Azaların müşkül anlarındaki nakdi ihtiyaçlarının borç verme suretiyle karşılamak. 2-Azaları tasarrufa teşvik etmek. 3Azalarının mesken sahibi olmalarını sağlamak" (BCA, 490.01/93.365.4/1). CHP yardım sandığından yararlanmak için öncelikle CHP Genel Sekreterliği'ne bağlı olarak çalışmak ya da partinin herhangi bir organında yer almak yeterlidir (BCA, 490.01/93.365.4/1). Bu kuruluşun idaresi, umumi heyet, idare heyeti ve mürakiplerden oluşmaktadır. CHP Genel Sekreterliği bu kuruluşun mali olarak desteklenmesi konusunda Türkiye İş Bankası'ndan ciddi manada yardım aldığı anlaşılmaktadır. Diğer taraftan yardım sandığı borç verdiği kişilere borçlarının taksitle ve bir yıl içinde ödenmesi konusunda taaddüt istemiştir. Yardım sandığının gelirleri arasında, partiye yapılan bağışlar, bankadaki mevduat faizleri, ikraz faizleri, teberrular, sandığa vaki olacak mevduatlar, umumi heyetçe kabul edilecek diğer gelirler, pul beyiye hasılatı önemli kalemler arasındaydı (BCA, 490.01/93.365.4/7). Yardım sandığının dönemsel faaliyetleri her yıl toplu olarak ilan edilirdi. Genellikle yardım sandığına başvuranların evlenmek için, sünnet masrafları, ev satın alma, cenaze giderleri amacıyla başvurduğu görülmektedir. Sandığın başkanlığını genel sekreter ya da genel sekreterin atayacağı kişi yapacaktır (BCA, 490.01/84.311.1/5).

Yardım sandığı umumi heyet tarafından idare edilirdi. Buna göre umumi heyet 1 Temmuz'da göreve başlar sonraki yılın 31 Haziran'ına kadar görevde kalırdı. Umumi heyet bir başkan iki kâtip tarafından yönetilirdi. Umumi heyetin dışında bir de Sandık İdare Heyeti ve Murakabe Heyeti vardı. Sandık İdare Heyeti beşi yedek olmak üzere on kişidir. En fazla oyu alan beş kişi asıl üye olur. Murakabe Heyeti ise Genel Sekreter tarafindan belirlenecek iki kişi tarafindan idare edilir. Yedekleri yoktur (BCA, 490.01/84.311.1/7). İdare Heyetinin vazifeleri şunlardır: 1-Sandık işlerini ve çalışmalarını tanzim etmek, hesap ve karar defterlerini ve azaların cüzdan kayıtlarının ve diğer muamelelerini muntazam bir şekilde tutmak 2-Sandığ1 maksada uygun bir şekilde idare etmek 3Hesap senesi sonunda bilanço ve kâr ve zararı çıkarmak 4-Geliri nemalandırmak 5-İstikrazlar hakkında karar vermek 6-Azaların taahhüt ettikleri meblağları toplamak (BCA, 490.01/93.365.4/5).

Yardım sandığına herkes başvuramamaktadır. Sandığa dahil olmak için öncelikle partinin herhangi bir biriminde görev almak ya da genel sekreterliğe bağlı memur olmak gerekiyordu. Yardım sandığına giriş için öncelikle 5 lira giriş parası ve azalar için iştirak talepnamesinin doldurulup imzalanması elzemdi (BCA, 490.01/93.365.4/10). Yardım sandığından herkes para yardımında bulunamazdı. Öncelikle yardım isteyen kişilerin yardıma muhtaç olup olmadığı kontrol edilirdi. Diğer taraftan yardımın yerinde kullanılması da yardım sandığının başlıca görevleri arasındaydı. Bu sebeple disipline edilmiş bir iş yükünden bahsetmek mümkündü. Yardım sandığından alınan yardım paraları eğer ki memur görevinden ayrılırsa yardım sandığından aldığı parayı derhal geri ödemek zorundaydı. 1946 yılında halkevlerinde olarak çalışan Ferruh Arsunar adlı kişi, görevinden ayrılma durumu oluşunca, yardım sandığı Arsuvar'ın aldığı 288 Lira'nın geri iade edilmesini istemiştir (BCA, 490.01/87.327.1/3). Tüm bu yazışmalar halkevi, yardım sandığ 1 ve paranın alındığg ve verildiği banka olan Türkiye İş Bankası arasında gerçekleşmiştir. Yardım sandığı bilhassa gelirlerini artırma adına 
balolar düzenlediği ve balo gecelerinde piyango bileti satma yolunu seçtikleri de görülmüştür (BCA, 490.01/34.315.4). Ayrıca CHP rozetlerinin yapılması ve satılması da sandığa destek sağlama yolları arasında yer almaktadır. Zaten kuruluş nizamnamesinde yardım sandığı gelirlerini artıcı faaliyetlerde bulunabilirler ibaresi bulunmaktadır.

\section{Yardım Sandığının Yaptığı Toplantılar ve Faaliyetleri}

Yardım sandığının faaliyetlerinin değerlendirildiği toplantılarda genellikle geçmiş bir yılın muhasebesi ele alınmaktaydı. Toplantıya konu olan mevzular değerlendirme süzgecinden geçirilerek, elde edilen paranın miktarı, paranın nelere gittiği yani özetle geçmiş bir yılın fotoğrafı ele alınır ve gelecek döneme ait yapılması gerekenler de ele alınırdı. Düzenli olarak gerçekleştirilen toplantılarda genel sekreterliğini temsilen bir milletvekili olmasına dikkat edilirdi. Buna göre eldeki belgelere göre yıllara göre gerçekleştirilen toplantılardaki genel değerlendirme şöyledir:

1943 yılında yeni kurulması hasebiyle kurumsallaşmanın tam olarak sağlanamadığı ve özellikle görevlendirme ve atamaların yapılması sisteminin henüz yerleşmediği 1944 yılında gerçekleştirilen toplantının başında belirtilmiştir. Toplantıda öncelikle yardım sandığının başında bulunan Daime Nazikioğlu'nun işlerinin yoğunluğu sebebiyle istifa ettiği yerine önce idare heyetinde yapılan seçimde en çok oyu alan Rasim Demirok geçmiş, Rasim Bey bu görevden 3 ay sonra ayrılmış bu defa yerine Mimar Sabri Onar seçilmiştir. Sabri Bey de bu görevde uzun süre kalmadığı ve bu defa yerine Sadi Evren geçmiştir (BCA, 490.01/86.323.4/3). Görülüğü gibi kurumsallaşma bir türlü sağlanamamıştır. Toplantı esnasında 1943 yılı için yardım sandığına üye olanlardan toplam 4300 lira alınmıştır. Genel sekreterlik yardım miktarını az bulunca 3000 lira yardımda bulunmuş böylece toplam gelir 7300 liraya yükselmiştir. Balo ve piyango işlemleri, pul ve tayyare biletleri gibi faaliyetlerden herhangi bir gelir elde edilememiştir.

1943 yılı içerisinde 103 kişi sandığa üye olmuştur. 44 kişiye nakdi yardımda bulunulduğu, 58 üyesine odun, 70 üyesine ise $5 \mathrm{~kg}$ zeytin, sabun verilmiştir. Üyelere pirinç ve sadeyağı da verilmek istenmiş ancak nakdi para az olduğundan başarısız olduğu belirtilmiştir. 1943 yılı 812 lira karla kapatıldığı da ifade edilmiştir. Toplantıya Ankara Milletvekili Naci Mıhcıŏlu da katılmıştır (BCA, 490.01/86.323.4/4). Toplantı sonrası yardım sandığına üye olacak kişilerin artacağı ve yardım gelirlerini artırma yolunda faaliyetler yapılması gerektiği de belirtilmiştir.

1944 yılı faaliyet raporu Mayıs 1945 yılında kaleme alınmıştır (BCA, 490.01/86.323.4/1). Rapor neticesinde üyelerden 57 bin lira kadar para toplandığı, bunun 56 bin lirasının harcandığı belirtilmektedir. Raporda genel sekreterliğin 3 bin lira nakdi yardım yaptığı buna ilaveten bin lira da sosyal yardımlaşmada kullanılmak üzere bütçe ayrıldığı ifade edilmektedir (BCA, 490.01/86.323.4/2). Genel sekreterliğin verdiği 3 bin liranın 1750 lirası üyelerden bazılarının evlenmeleri için 1250 lirası verilmiş, geriye kalan tutar ise ölen kişilerin masrafları için harcandığı not edilmiştir. 1944 yılı için üyelere 8 bin lira zeytinyağı ve sabun yardımında bulunulmuştur. Aynı yıl yardım sandığına üye olan kişilerin toplamı 102 olarak kaydedilmiştir. Yardım sandığının 1944 yılı içerisinde yapılan yardımlar ve üyelerin istedikleri nakdi yardımlar çıkarıldıktan sonra yaklaşık 2 bin lira 1945 yılı bütçesine İş Bankası'na yatırıldığı ifade edilmektedir.

1945 yılının tüm ayını kapsayan olağan toplantısında toplam bütçenin 36 bin lira olduğu 31 bin lirasının ise kullanıldığı belirtilmiştir. Yardım sandığına toplam 99 kişinin başvurduğunu çoğunun borç isteklerinin karşılandığı not edilmiştir. Ayrıca 1945 yılı bütçesi içinde 39 kişiye 2500 lira odun yardımı yapılmıştır. Ayrıca yardım sandığına bağlı üyeler için çamaşırlık, kumaş, şeker, sabun, pirinç gibi ihtiyaçların karşılanması için 16 bin lira para harcandığ 1 yazmaktadır. Toplantının sonunda üye sayısının artırılması ve yardım sandığının bütçesinin yeterli düzeye getirilmesi kararı da alınmıştır (BCA, 490.01/87.327.2). 1945 yılı içerisinde yardım sandığı için olağan toplantının yanında 6 Ağustos 1945 tarihinde olağanüstü toplantı da gerçekleştirilmiştir (BCA, 490.01/86.323.4/1). Toplantıyı Genel İdare Kurulu üyesi Muğla Milletvekili Hüsnü Kitapçı açmıştır. Toplantıda, yardım sandığı başkanlığına Halim Cevap Alcak, sekreterliğe de Necdet Yula ve Cevat Şumnu seçilmiştir. Ayrıca ölen çalışanların çocuklarına yapılacak yardım miktarı, evlenecek kişilere verilecek nakdi yardım ve 
daha önce yardım sandığına üye olamayan hizmetlilerin de bu teşekküle üye olabilmesinin yolu açılmıştır. Toplantıda son olarak suçlu ya da suçsuz olarak memuriyetten çıkarılanların yardım sandığına verdikleri aidatların kişiye ödenebilmesi de kabul edilmiştir (BCA, 490.01/86.323.4/4).

1946 yılına ait idare heyetinin gerçekleştirdiği toplantıya göre 31 bin lira sermayenin bu yıl içerisinde 29 bin liraya düştüğü belirtilmektedir (BCA, 490.01/88.333.2/1). Bunun sebebini de yardım sandığından ayrılanlara bağlanmaktadır. Yaklaşık 16 bin lira kadar sermayenin yardım sandığından çekilmelerinden dolayı azaldığına dikkat çekilmektedir. Üye sayısı 103 iken, 88'e düşmüştür. Yardım sandığına üye olmayan kişilerce 53 kişinin yakacak yardımı için başvuruda bulunduğu ve 3500 liranın yardım sandığı bütçesinden karşılandığı belirtilmektedir. Diğer taraftan 10 bin lira kadar üyelere yiyecek ve giyecek yardımında bulunulmuştur (BCA, 490.01/88.333.2/4). 1946 y1lına ait hesaplarda yardım sandığına ait geri kalan parayla 11 bin lira ihraç ve 12 bin lira da tahvil bonosu alındığı yer almaktadır.

İdare Heyeti'nin 1947 yılı içerisinde yaptığı olağan toplantı kayıtlarına göre yardım sandığına 147 kişi çeşitli vesilelerle yardım almak için başvuruda bulunmuştur. Buna göre hepsinin başvurusu kabul edilmiştir. Bu başvurular neticesinde bankadan 20 bin lira ödeme yapıldığı ayrıca 2720 liraya yağ, 2477 liraya kumaş, 2600 liraya da odun alınarak durumu zayıf olan memurlara verildiği belirtilmiştir (BCA, 490.01/89.343.4/6). Öte yandan genel sekreterliğe bağlı olarak odacı olarak çalışan ve vefat eden Ali Başkara'nın ailesine 100 lira yardım yapıldığı not edilmiştir. Ali Başkara'nın yardım sandığına üye olmamasına rağmen yapılan tetkik sonucu ailesinin mali durumu kötü olduğu belirtilmiş ve bu sebeple mali yardım yapıldığı da ifade edilmiştir. Aralık 1947 itibariyle yardım sandığının İş Bankası'nda 147 bin liranın olduğu bunun sadece 40 bin lirasının kullanıldığı görülmektedir (BCA, 490.01/89.343.4/6).

İdare Heyeti’nin 14 Eylül 1948 tarihinde yapmış olduğu olağanüstü toplantı tutanaklarına göre genel sekreterliğe bağlı memurların kendi aralarında istişareler halinde yaptıkları toplantıya göre ev kiralarının çok yüksek olduğunu bildirilmiştir. Memurlar verdikleri kiralarla 15-20 yıl içeresinde ev sahibi olabileceklerini belirtmişler. Bunu sağlamak için İdare heyetinin iş bankası ile görüşerek bir arsa tahsisi için kredi verilmesini talep ettiler. Bu arsaya iki, üç ve dört odalı şekilde evlerin yapılacağını bunun da Emlak ve Kredi Bankası'nın finanse etmesine yönelik görüşlerini ifade ettiler. Toplantıya başkanlık eden Erzurum Milletvekili Münir Hüsrev Göle, toplantı neticesinde bu durumu genel sekreter ile görüşeceğini belirtmiştir (BCA, 490.01/88.388.2/3). Raporun son kısmında Münir Göle rapor doğrultusunda çalışacağını belirterek:

\footnotetext{
"Memurların talip oldukları ev tiplerine göre ilk dört yıl için yâni İş bankası ile Emlâk ve Kredi Bankasına tediye edilecek taksitlere ait cetveller tahmin esaslarına tespit edilmiştir. Bu miktarların memurların katlanabileceği fedai karlık hududu içerisinde bulunduğu görülmüştür. Hayatlarını ve istikballerini partimize bağlamış bulunan memurlarımızın birer ev sahibi olmaları hususundaki dilleklerinin nazarı itibar alınarak yukarıda tespit edilmiş esaslar dairesinde mümkün olan yardım ve kolaylıkların teminine dair izin ve emirlerinizi üstün saygılarımla arz ederim" (BCA, 490.01/88.388.2/4).
}

1948 yılının olağan toplantısında ise hesapta 8.911 lira paranın toplandığı bunun 8900 lirasının yardım istekleri için kullanıldığı, sosyal yardımlar içinse iş bankası ve genel sekreterlikten nakdi yardım alındığı belirtilmektedir (BCA, 490.01/90.348.1/2). Yardım sandığına üye olan memurların, üyelikten ayrılmaları konusunda genellikle bir zorluk çıkarılmazdı. Gerekli olan sadece gerekçeli sebebin bir dilekçe ile genel sekreterliğe başvurulması gerekiyordu. Örneğin Konya iline mensup Hüseyin Kara adlı şahıs, çocuğunun doğduğunu bu suretle yardım sandığının kendisine verdiği yardımın yetmediğini ve bu sebeple şimdiye kadar yardım sandığında toplanan 319 lirasının verilmesini istemektedir. Genel Sekreterlik Memurları Biriktirme ve Yardım Sandığı Başkanlığı'na verilen dilekçede yer alan unsurları doğrultucu belgeler ışığında Hüseyin Kara'nın dilekçesinin kabul edildiğini yardım sandığına yazılan yazıyla paranın İş Bankası yoluyla ödenmesini talep etmektedir (BCA, 490.01/89.343.3/3). 1944 yılında ise Vehbi Okaya adlı kişi de bazı sebeplerden dolayı yardım sandığından çıkmak istediğini, biriken 287 liranın kendisine verilmesini istemiştir (BCA, 490.01/85.321.4/1). Yardım sandığına başvuranlarla ilgili örnekleri artırmak mümkündür. Yine yazı 
işlerinde göre Leman Eke adlı kişi çocuklarının masraflarının artmasından dolayı maaşından yardım sandığ 1 kesintisinin ailesini ciddi manada etkilediğini bu sebeple şimdiye kadar maaşından kesilen yardım sandığı aidatlarının toplanarak kendisine verilmesini istemiştir (BCA, 490.01/91.356.3/2). Saadet Tanyer adlı muhasebede görevli kişi gördügü lüzum üzerine yardım sandığından ayrılmak istediğini belirtmiş ve 575 liranın iş bankası yoluyla kendisine verilmesini talep etmiştir (BCA, 490.01/91.352.6/2). Öte yandan yardım sandığ1 üyelerinden Mürüvvet İlkiz 1946 yılında yaptığ1 başvuruda CHP Yardım Sandığı’ndan ayrılmak istediğini beyan etmiş ve biriken 406 lirasını İş Bankası üzerinden kendisine verilmiştir (BCA, 490.01/87.327.7/2). Bir başka örnek ise Halkevinde memur olarak görev yapan Rabia Dinçman ile ilgilidir. Rabia Hanım halkevindeki görevi sona erdiğini bir başka yerde memuriyete başladığını bu sebeple yardım sandığındaki birikmiş olan 225 lirasını talep etmektedir. Talep karşısından yardım sandığı Rabia Hanım'a verilmek üzere senedi iş bankasına yönlendirilmiş olup paranın iş bankasından alınacağını Rabia Hanım'a bildirmiştir (BCA, 490.01/87.330.5). Aynı şekilde 1946 yılında Halkevinde görevli olan Naciye Gürakar adlı kişi görevinden ayrılmış olduğundan yardım sandığında toplanan 29 lirasının kendisine verilmesini talep etmiştir (BCA, 490.01/87.331.3). Aynı yıl içerisinde Abdülkadir Asena adlı şahıs memuriyetten istifa etmesi sebebiyle şimdiye kadar toplanan 859 liranın kendisine verilmesini istemiş̧ir (BCA, 490.01/87.330.1). Arşiv belgelerinden anlaşılacağ üzere yardım sandığına başvuranların büyük kısmı borç içinde bulunduğunu, bir kısmı ev satın almak istediği, bir kısmı sahip olduğu evi tamirattan geçireceğini, bir kısmı okuyan çocukları için istediği görülmektedir.

Yardım sandığına başvuruların önemli bir kısmı sandığın üyeleri olan kişilerin ölümünden sonra eşlerinin istekleri üzerine yapılan nakdi yardımlardır. Bu nakdi yardımlar hemen hemen her yıl dile getirilmektedir. Örneğin 1948 yılında Halim Cavit Arcak vefat edince eşi Vahide Hanım yardım sandığına başvurarak ölüm parasının kendisine verilmesini istemiştir (BCA, 490.01/89.344.2). Yine 1949 yılında eşi ölen Hadiye Acar, eşinin ölüm parası olan 210 liranın kendisine takdim edilmesini belirtmektedir (BCA, 490.01/91.354.1). Yardım sandığına başvuran kişilerin hemen hemen birçoğunun istekleri kabul edilmeye azami ölçüde dikkat edilmiştir. Ancak yardım sandığı nizamnamesine göre yardım sandığına üye olan kadınların isteklerinin hepsinin makul ölçüde olması koşuluyla kabul edilmesi kararı vardır. Bu amaçla 1949 yılında halkevinde görevli olan Necla Noyan yaşadığı ekonomik sıkıntılar sebebiyle 125 liralık yardım talebi yardım sandığı idare heyeti tarafından kabul edilmiştir (BCA, 490.01/90.350.1). 1944 yılında CHP'de görevli Şükrü Asal, yaşadığı maddi sorunlar nedeniyle biriktirme ve yardım sandığına toplam 250 lirayı 9 taksitle ödemek konusunda başvuruda bulunmuştur (BCA, 490.01/85.319.4). 1949 yılında Hamdi Tümer adlı bazı ihtiyaçlardan dolayı 100 liraya ihtiyacı olduğunu geriye 9 taksitte ödemek koşuluyla yardım sandığına başvurmuştur. Hamdi Bey'in başvurusu devam ederken, bu defa rakamın 200 liraya çıkarılmasını talep etmiş ve bu talep kabul edilmiştir (BCA, 490.01/92.360.2).

Yardım sandığından alınan yardımların her daim düzenli olarak geri ödendiği söylenemez. Yardım alan kişilerin bazı sebeplerden dolayı taksitlerini ödeme konusunda sıkıntı yaşadıkları anlaşılmaktadır. Örneğin 1949 yılında Arşiv Şefi Süreyya Duman'ın almış olduğu yardımın taksitlerini ödeme konusunda sorun çıkardığı, alınan yardımdan 300 liranın her ayın 20'sinde taksitle geri ödenmesi ve paraya karş1 kefil göstermesi istenmiştir (BCA, 490.01/90.343.3/8). Aynı y1l içinde CHP arşivinde görevli Hasan Hüseyin Yücel adlı şahıs, bir çocuğunun beş aydan itibaren aldığ 1 yardım parasını akıl hastalığına diğer çocuğunun da boğmaca hastalığına yakalandığını bu sebeple çocuklarının tedavileriyle meşgul olduğunu ve yardım sandığından aldığı paranın taksitini ödeyemediğini belirtilmektedir. Bu sebeple yardım sandığının kendisine kolaylık sağlamasını ve borçlarının tasfiye edilmesini vurgulanmaktadır (BCA, 490.01/87.327.7/2). Yine Fazıl Nalbantoğlu şahıs yardım sandığına 150 lira borçlu olduğunu ancak taksit ödemeleri sırasında ciddi sıkıntı yaşadığını aldığı ve tarafına 480 lira da borç verilmesini bu 480 liradan 150 lira borcun alındıktan sonra geriye kalan tutarın kendisine verilmesini ve borç taksitlenmesini de 6 ay sonra başlamak üzere 9 taksitle verilebileceğini belirtmiştir (BCA, 490.01/90.348.3).

Yardım sandığından üyesi olan ve yardımlaşma adı altında parasını yardım sandığına bağışlayan üyeler de bulunmaktadır. Örneğin 1945 yılında Doğan Köymen adlı kişi 312 lirasının tümünü yardım sandığına bağışladığını belirtmiştir (BCA, 490.01/86.324.6). Yardım sandığını üyelik 
dışında da bütçesini artırmak adına ticari faaliyetlere de girişmiştir. Örneğin 1946 yılında yardım sandığında görevli Süreyya Duman adlı kişi 1000 adet altı oklu parti rozetini tanesi 80 kuruştan yapılması konusunda bir firma ile iletişime geçtiğini ve bu rozetleri partililere tanesi 1 liradan satılmak konusunda anlaştı̆̆ını böylece buradan gelen karla yardım sandığına katkı bulunacağını ifade etmiştir (BCA, 490.01/87.329.1).

\section{Yardım Sandığının Faaliyetlerinin Durdurulması}

14 Mayıs 1950 Genel Seçimleri ile iktidara gelen Demokrat Parti, CHP'ye yönelik başlarda bir çatışma içerisine girmekten kaçınmıştır. Ancak zamanla özellikle bürokrasi ve memurların kendisine karşı olduğunu ve CHP'ye ait sosyal, ekonomik ve basın gibi önemli güçleri zayıflatmak amacıyla birtakım uygulamalara girişmiştir. Bu girişimlerden biri de halkevlerinin kapatılması akabinde CHP'ye ait malların hazineye devri mevzusu gündeme gelince CHP Genel sekreterliğine bağlı yardım sandığının da geleceği tartışılmaya başlandı. Zaten üyelerin katılımıyla var olan bu kurum, memurların da Demokrat Parti (DP) tarafına geçmesi nedeniyle hem üye hem de bütçe konusunda ciddi bir zafiyet yaşandığı görülmektedir. 8 Ağustos 1950 tarihinde Genel Sekreterlik Yardım Sandı̆̆ı'na görevlendirilen İhsan Erbaskın öncülüğünde hem üye sayısı hem de genel durumun tespitiyle ilgili bir toplantı gerçekleştirilmiştir (BCA, 490.01/93.364.1/3).

Toplantı sonucu alacaklı olanların alacaklı listesi hazırlanmış ve kısa zamanda ödeme yapılacağını, öte yandan yardım sandığına borcu olanların ise kesintilerle bu borcun kapatılacağı belirtilmiştir (BCA, 490.01/93.364.1/5). Toplantıda yardım sandığında 4871 lira para olduğu da ifade edilmiştir (BCA, 490.01/93.363.2/1). Yardım sandığının tam olarak ne vakit tasfiye edildiğine dair ne arşiv belgelerinde ne de basın arşivinde herhangi bir bilgiye rastlanılamadı. Ancak 1951 tarihli bir belgede daha önce halkevinde görevli olduğunu belirten Abdullah Kaya Berker adlı vatandaş yıllarca yardım sandığına maaşından para aktardığını ve bu parayı ara ara kullandığını ancak yardım sandığının kapatılmasından sonra geriye kalan 10 bin lirasını bir türlü temin edemediğini bu konuda kendisine yardım olunmasını CHP Genel Sekreterliği'nden istemektedir (BCA, 490.01/93.364.1/4). Belgeden anlaşıldığı üzere yardım sandığı resmi olarak tasfiye edilmesine rağmen üyelere ait borç ya da alacakla ilgili sürecin devam ettiği anlaşılmaktadır.

\section{Sonuç}

İkinci Dünya Savaşı'na Türkiye fiili olarak girmemesine rağmen sosyal, siyasi, ekonomik, toplumsal anlamda ciddi sıkıntılar yaşadığı anlaşılmaktaydı. Savaşın ilk yıllarında özellikle üretimde yaşanan sert düşüş, ithalatın artmasına ihracatın da azalmasını beraberinde getirdi. Hükümet, özellikle yaşanan ekonomik sıkıntıların farkında olacak ki üst üste getirdiği sınırlamalarla savaş ekonomisini yönetmeye çalıştı. Zira savaşın ilk yıllarında kısıtlamalar gelince temel gida maddelerinden tutun da günlük ihtiyaçlar içerisinde yer alan ürünleri bulmak zorlaştı ya da karaborsa oldu. Karaborsa, tefecilik gibi ifadeler bu dönemde kurumsallaşmaya başlamıştı. Hükümet bu gibi kavramları anlamsızlandırma adına Milli Koruma Kanunu, Varlık Vergisi vb. kanunlarla sorunları çözmeye çalıştı. Ancak bu konuda çok da başarılı olduğu söylenemez.

Hükümetin bilhassa savaşın getirdiği yükün karşısında ezildiğini düşündügü memurlar için birtakım kolaylıklar da getirdi. Sosyal devlet adına ucuz ekmek, şeker, yağ gibi temel gıdaların temini odun gibi yakacağa ulaşmaları için çalışmalar yürüttü. Tüm bunlara binaen CHP Genel Sekreterliği kendi uhdesinde çalışan memurların isteği üzerine oluşturmuş olduğu yardım sandığı İkinci Dünya Savaşı döneminde parti bilişsel düzeyinin artırılması ve memurların karşılaştığı sorunların çözümü konusunda önemli bir vazife üstlenmiştir. Yürürlükte kaldığı on y1l boyunca incelenen belgeler ışığında yardım sandığı memurlara yaraların sarılması, tefecilik ve istifçilik karşısında sığınacağı bir liman olmuşa benziyor. Genel Sekreterliğine bağlı olarak faaliyetlerini sürdüren yardım sandığı, işlevi ve kurumsal yapısıyla daha sonra ki birçok kamu personeli için örnek olmuştur. Bu yardım sandığını örnek alarak birçok yardım sandığı daha sonraki yıllarda kurulmuştur. Yardım sandığı kültürünün Türkiye'de oluşmasında önemli bir vazifeyi üstlenen genel sekreterlik yardım sandığı, çalışanların sağlık, eğitim, kira gibi sorunların çözümünde ya da ev almalarına yardımcı olduğu söylenebilir. 
Yardım sandığı her yıl düzenli olarak yaptığı olağan ve olağanüstü toplantılarla yardıma başvuran memurların durumunu görüşürken, yardım sandığının bütçesiyle ilgili de değerlendirme yapmıştır. Diğer taraftan yardım sandığı yönetimi hem bütçenin artırılması hem de sosyal yardımların daha fazla memura ulaşması için çalışma yürüttüğü anlaşılmaktadır. Sonuç olarak kuruluşu sırasında üye bulmakta zorlanan bu kuruluş, sonra ki yıllarda üye sayısının arttığı görülmüş, sona doğru ise CHP'nin iktidardan uzaklaşmaya başlamasıyla birlikte üye olanların birikimini yardım sandığından çektiği gözlenmiştir. Özellikle iktidarın Demokrat Parti'ye geçmesiyle birlikte yardım sandığının kapatıldığı üye olan kişilere ödeme yapılmak suretiyle bu kuruluşun kendi kendisinin feshetmesine zemin hazırlamıştır.

\section{Yazarların Katkı Oranı}

Çalışma tek yazarlı olduğu için yazarın katkı oranı \%100’dür.

\section{Çıkar Çatışması}

Bu çalışmada çıkar çatışması oluşturacak bir husus yoktur.

\section{Kaynaklar}

Ataay, I. D. (1974). Türkiye'de elli y1llık maaş ve ücret uygulaması. İstanbul Üniversitesi İsletme Fakültesi Dergisi, 3(1) 430-455.

Avcıŏlu, D. (1996). Türkiye'nin düzeni . İstanbul: Tekin Yayınları.

Aydemir, Ş. S. (1993). İkinci adam 1884-1938. İstanbul: Remzi Kitapevi.

Bakırc1, F. (2006). Meclis üyelerinin aylık ve diğer ödenekleri. Yasama Dergisi, (3), 27-70.

Barutçu, F. A. (1977). Siyasi anılar 1939-1954. Milliyet Yayınları: İstanbul.

Başbakanlık Cumhuriyet Arşivi (BCA) (1942-1951)

BCA, Fon Kodu 490.01. Yer Numaras1: 34.315.4.

BCA, Fon Kodu 490.01. Yer Numaras1: 85.319.4.

BCA, Fon Kodu 490.01. Yer Numaras1: 86.324.6.

BCA, Fon Kodu 490.01. Yer Numaras1: 87.327.2.

BCA, Fon Kodu 490.01. Yer Numaras1: 87.330.5.

BCA, Fon Kodu 490.01. Yer Numaras1: 87.331.3.

BCA, Fon Kodu 490.01. Yer Numaras1: 87.330.1.

BCA, Fon Kodu 490.01. Yer Numaras1: 87.329.1.

BCA, Fon Kodu 490.01. Yer Numaras1: 89.344.2.

BCA, Fon Kodu 490.01. Yer Numaras1: 90.350.1.

BCA, Fon Kodu 490.01. Yer Numaras1: 90.348.3. 
BCA, Fon Kodu 490.01. Yer Numaras1: 91.354.1.

BCA, Fon Kodu 490.01. Yer Numaras1: 92.360.2.

BCA, Fon Kodu 490.01. Yer Numarası: 93.365.4.

BCA Fon Kodu 490.01. Yer Numaras1: 88.333.2/1.

BCA, Fon Kodu 490.01. Yer Numarası: 93.363.2/1.

BCA, Fon Kodu 490.01. Yer Numaras1: 93.365.4/1.

BCA, Fon Kodu 490.01. Yer Numaras1: 86.323.4/1.

BCA, Fon Kodu 490.01. Yer Numaras1: 85.321.4/1.

BCA, Fon Kodu 490.01. Yer Numaras1: 90.348.1/2.

BCA, Fon Kodu 490.01. Yer Numaras1: 91.356.3/2.

BCA, Fon Kodu 490.01. Yer Numaras1: 86.323.4/2.

BCA, Fon Kodu 490.01. Yer Numaras1: 91.352.6/2.

BCA, Fon Kodu 490.01. Yer Numaras1: 87.327.7/2.

BCA, Fon Kodu 490.01. Yer Numaras1: 84.311.1/3.

BCA, Fon Kodu 490.01. Yer Numaras1: 87.327.1/3.

BCA, Fon Kodu 490.01. Yer Numaras1: 93.364.1/3.

BCA, Fon Kodu 490.01. Yer Numaras1: 88.388.2/3.

BCA, Fon Kodu 490.01. Yer Numaras1: 89.343.3/3.

BCA, Fon Kodu 490.01. Yer Numaras1: 86.323.4/3.

BCA, Fon Kodu 490.01. Yer Numaras1: 84.311.1/4.

BCA, Fon Kodu 490.01. Yer Numaras1: 93.364.1/4.

BCA, Fon Kodu 490.01. Yer Numaras1: 88.333.2/4.

BCA, Fon Kodu 490.01. Yer Numaras1: 86.323.4/4.

BCA, Fon Kodu 490.01. Yer Numarası: 84.311.1/5.

BCA, Fon Kodu 490.01. Yer Numaras1: 93.364.1/5.

BCA, Fon Kodu 490.01. Yer Numaras1: 89.343.4/6.

BCA, Fon Kodu 490.01. Yer Numaras1: 93.365.4/7.

BCA, Fon Kodu 490.01. Yer Numaras1: 90.343.3/8. 
BCA, Fon Kodu 490.01. Yer Numaras1: 93.365.4/10.

Berktaş, E. Z. (2014). Kara defter Atatürk'ün silah arkadaşı İhsan Eryavuz anlatıyor. İstanbul: Timaş Yayınları.

Boratav, K. (1990). Türkiye iktisat tarihi 1908-1985. İstanbul: Gerçek Yayınları.

Demirel, A. (2003). Birinci Meclis 'te muhalefet ikinci grup. İstanbul: İletişim Yayınları.

Ergin, F. (1943). Harp zamaninda devletin ekonomiye müdahalesi. İstanbul: Cumhuriyet Matbaas1.

Gündoğdu, C. (2004). Illk Meclis anketi birinci dönem TBMM üyelerinin gelecekten bekledikleri. Ankara: TBMM Kültür, Sanat ve Yayın Kurulu Yayınları.

Hafızoğulları, Z. (2000). İzmir iktisat kongresi görüşler ve değerlendirmeler. Atatürk Araştırma Merkezi Dergisi, 16(46), 289-311.

Kansu, M. M. (1986). Erzurum'dan ölümüne kadar Atatürk'le beraber. Ankara: Türk Tarih Kurumu Basimevi.

Karaosmanoğlu, Y. K. (1984). Politikada 45 yıl. İstanbul: İletişim Yayınları.

Metinsoy, M. (2016). İkinci Dünya Savaşında Türkiye dündelik yaşamda devlet ve toplum. İstanbul: Türkiye İş Bankası Kültür Yayınları.

Nennioğlu, S. Y. (2018). Osmanlı'dan Cumhuriyet'e bir sosyal yardım uygulaması: Hıdemât-I Vataniye Tertibinden Bağlanan Maaşlar (1909-1938). Yüksek Lisans Tezi, Pamukkale Üniversitesi, Sosyal Bilimler Enstitüsü, Denizli.

Nur, R. (1967). Hayat ve hatıratım. İstanbul: Altındağ Yayınevi.

Pektaş, Ş. (2003). Milli Şef döneminde(1938-1950) cumhuriyet gazetesi. İstanbul: Fırat Yayınları.

Seviğ, V. R. (1951). 23 Nisan 1919'dan 24 Nisan 1924'e kadar anayasa hareketleri. Ankara $\begin{array}{lllll}\text { Üniversitesi Hukuk Fakültesi } & \text { Dergisi, } & \text { 8(1-12), } & \text { 1-72. }\end{array}$ https://doi.org/10.1501/Hukfak_0000000427\%C2\%A0.

Şapolyo, E. B. (1969). Mustafa Kemal ve birinci büyük millet meclisi. Ankara: Ülkemiz Yayınları.

Tekeli, İ. ve İlkin, S. (2014). İkinci dünya savaşı Türkiye’si. İstanbul: İletişim Yayınları.

Timur, T. (1993). Türk devrimi ve sonrası. Ankara: İmge Kitapevi.

Timur, T. (1994). Türkiye’de çok partili hayata geçiş. İstanbul: İletişim Yayınları.

Toker, M. (1998). Tek partiden çok partiye 1944-1950. İstanbul: Bilgi Yayınevi.

Tuğluoğlu, F. (2001). Tek parti döneminde hükümet memur dayanışması. Ankara Üniversitesi Türk Inkılâp Tarihi Enstitüsü Atatürk Yolu Dergisi, 7(27), 353-373. https://doi.org/10.1501/Tite_0000000282.

Türkiye Büyük Millet Meclisi Zabıt Cerideleri (TBMM ZC)

TBMM ZC, C. XXI, Devre II, 31.03.1926. 
TBMM ZC, C. XXIX, D. VI, 16, 16.12.1942.

Yuca, İ. S. (2016). I. TBMM'nin yardıma muhtaç mebusları meselesi. Uluslararası Sosyal Araştırmalar Dergisi, 9(42), 831-844. doi prefix: 10.17719/jis. 


\section{Extended Abstract}

\section{Introduction}

In the early years of the National Struggle, the civil service was considered as a duty to the throat toughness. In particular, insufficient housing, low wages are frequently mentioned by the working sector. Most of those who could not find housing stayed in the School of Education, the Ministry of Education. On the other hand, the fact that the cost of living in Ankara did not provide rent assistance to civil servants was among the important problems. There were even civil servants who could not receive wages for months. In fact, there were civil servants who received a salary every eight months in the first days of the Assembly. Civil servants' salaries were not generally paid every month. Turkey emerged from the war as a state would do irregular payments to civil servants until 1926. The official basis of civil servants was established with the Civil Servant Law No. 788, issued on 31 March 1926. Accordingly, it was accepted that the civil servant would receive a salary of at least 10 and a maximum of 150 lira. The absence of taxes on civil servant salaries partially led to a comfortable life for civil servants until 1931. However, with the economic problems, a certain amount of tax was collected from the salaries, and with the law numbered 1452, the salaries were newly regulated, accordingly, the highest civil servant salary was calculated as general manager 90 lira, the manager 45 lira, the lowest civil servant salary was 16 lira, and the document and file clerk were 16 lira . With the advent of the war, the state made some arrangements for civil servants to breathe comfortably.

Turkey entered World War II, although as the actual, serious difficulties have lived up to a country at war. Because the working population, who is a producer, is immediately under armament. The recruited working population has now become a consumer. The destruction brought by the war was not just physical. It brought with it a mental fatigue. Especially during the war, imports were stopped due to the fact that it was too expensive. Turkey tried to just come into a country selfsufficient in this period. So much so that this caused the depletion of food and consumer goods necessary for life. Although the state tried to help the people with the laws it had made against this rapid exhaustion, it was not successful. During this time, hoarding began to become widespread.

It also brought some conveniences for civil servants, who the government thought was crushed by the burden of war. He carried out studies to supply basic foods such as cheap bread, sugar, oil on behalf of the social state to reach fuel like wood. Therefore, the RPP General Secretariat has assumed an important duty in increasing the cognitive level of the party and solving the problems faced by the officers during the Second World War period, which was formed at the request of the officers working under its own guidance. In the light of the documents examined during the ten years that it has been in force, it seems that it is a port where the wounded officers took shelter in the face of wound healing, usury and hoarding. It has become an example for many public personnel, with its function of aid fund and its institutional structure, which continues its activities under the Secretariat General. Many aid boxes were established in the following years, taking this aid fund as an example. Fund of relief, which assumed an important task in the development of culture in Turkey to help fund employees' health, education, solving problems such as rent or buy a house said to be helping. While he was discussing the status of the officers who applied for help through regular and extraordinary meetings held regularly every year, he also evaluated the budget of the aid fund. On the other hand, it is understood that the aid fund management is working to increase the budget and to reach social workers. Generally, there was no difficulty for the officers who were members of the aid fund to leave membership. The only reasoned reason needed was to apply to the general secretariat with a petition. In the meetings where the activities of the aid fund are evaluated, the accounting of a previous year is generally discussed. The subject matter of the meeting was passed through the assessment filter, and the amount of money obtained, what the money was going to be, that is, a photograph of a past year in brief, and the things to be done for the next period were also covered. In regular meetings, it was paid attention to be a deputy representing his secretary general. 


\section{Method}

This study focuses on the RPP General Secretariat aid fund to reduce the social and economic problems brought by the world war. While trying to help the economic problems of the members of the aid fund, he tried to help increase the level of emotionality within the party. In the study, the reason for which the applicants applied to the aid fund applied was also specifically mentioned. In addition, the meetings and evaluations held regularly every year by the aid fund, which has been working for about ten years, are also included in the content of this study. In the last part of the study, the change in power is closed together with the aid chest and the members receive their savings from the aid chest.

\section{Conclusion and Discussion}

As a result, it was observed that the number of members increased in the following years, which was difficult to find members during its establishment, and towards the end, it was observed that the RPP's withdrawal from the aid fund with the help of its membership. Especially with the transition of the government to the Democratic Party, it has prepared the ground for the selfdissolution of this organization by paying the members who are closed to the aid fund. The creditor list of the creditors was prepared and the payments will be made in a short time, while those who owe the aid fund will be closed with deductions. 